\title{
Interactions between Cationic Liposomes and Drugs or Biomolecules
}

\author{
ANA MARIA CARMONA-RIBEIRO \\ Departamento de Bioquímica, Instituto de Química, Universidade de São Paulo, \\ Cx. Postal 26077 - 05513-970 São Paulo, SP, Brazil \\ Manuscript received on September 8, 1999; accepted for publication on September 15, 1999; \\ presented by José M. RIVEROS
}

\begin{abstract}
Multiple uses for synthetic cationic liposomes composed of dioctadecyldimethylammonium bromide (DODAB) bilayer vesicles are presented. Drugs or biomolecules can be solubilized or incorporated in the cationic bilayers. The cationic liposomes themselves can act as antimicrobial agents causing death of bacteria and fungi at concentrations that barely affect mammalian cells in culture. Silica particles or polystyrene microspheres can be functionalized by coverage with DODAB bilayers or phospholipid monolayers. Negatively charged antigenic proteins can be carried by the cationic liposomes which generate a remarkable immunoadjuvant action. Nucleotides or DNA can be physically adsorbed to the cationic liposomes to be transferred to mammalian cells for gene therapy. An overview of the interactions between DODAB vesicles and some biomolecules or drugs clearly points out their versatility for useful applications in a near future.
\end{abstract}

Key words: interactions, dioctadecyldimethylammonium bromide, phospholipids, liposomes, drugs, surfaces.

\section{INTRODUCTION}

Since their introduction as bilayer-forming synthetic compounds (Fendler 1980), dihexadecylphosphate (DHP) or dioctadecyldimethylammonium (DODA) salts have found many different uses in strategic applied areas (Carmona-Ribeiro 1992). In particular, synthetic cationic liposomes have been sucessfully employed to interact with negatively charged surfaces or biomolecules such as prokaryotic (Martins et al. 1997) or eukaryotic cells (Carmona-Ribeiro et al. 1997), antigenic proteins (Tsuruta et al. 1997), nucleic acids (Behr 1993), synthetic polymers and latex (Carmona-Ribeiro \& Midmore 1992, Lessa \& Carmona-Ribeiro 1996) and mineral surfaces (Rapuano \& Carmona-Ribeiro 1997). In this work,

E-mail: mcribeir@quim.iq.usp.br some of their most recent uses in several applied areas are shown.

In Figure 1, the several possibilities for closed bilayer vesicles as drug carriers are illustrated. A water soluble molecule (S) can be carried inside the water vesicle compartment, an hydrophobic molecule $(\mathrm{H})$ can be solubilized in the hydrophobic moiety of the bilayer and an amphiphilic drug (T) can be partitioned between the bilayer and the water phase (Figure 1). Supported bilayers (CarmonaRibeiro \& Midmore 1992, Rapuano \& CarmonaRibeiro 1997) or monolayers (Carmona-Ribeiro \& Herrington 1993) have been described using silica or polystyrene particles (latex) (Figure 1). The hydrophobic/hydrophilic nature and the presence of electric charge on the solid sup- 


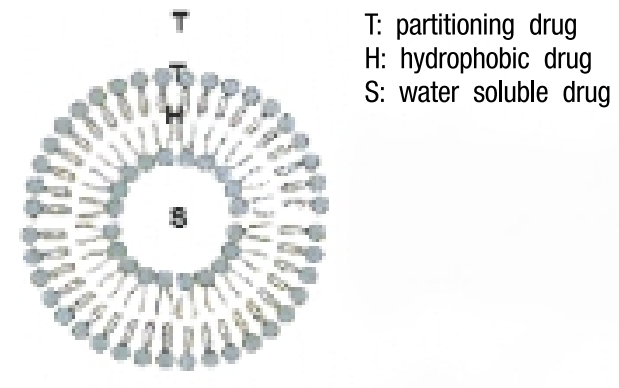

Functional microspheres
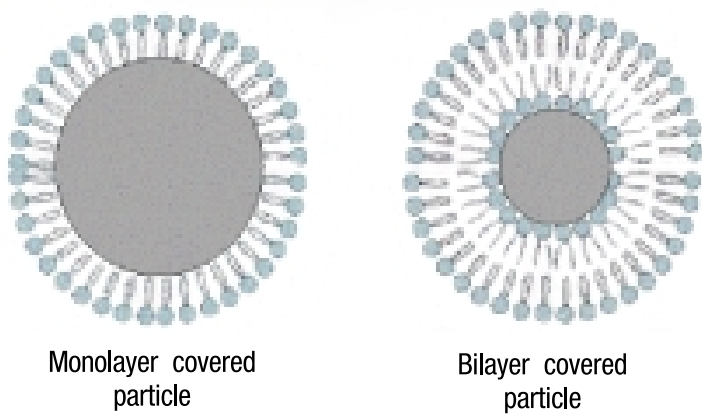

Fig. 1 - Bilayer vesicles and liposomes as drug carriers or as sources of organized supramolecular assemblies to cover solid particles.

porting particle have a major role in determining the lipidic supramolecular assembly obtained at the solid surface. The negatively charged nature of sulfate polystyrene microspheres leads to deposition of cationic bilayers onto the surface and vice-versa (Carmona-Ribeiro \& Midmore 1992) whereas the neutral character of phosphatidylcholine (PC) or dipalmytoylphosphatidylcholine (DPPC) leads to monolayer coverage of amidine latex with the phospholipid polar heads uppermost and the lipid hydrocarbon tails hydrophobically interacting with the latex surface (Carmona-Ribeiro \& Herrington 1993).

The molar absorptivity for Amphotericin B, an hydrophobic drug currently used as a potent fungicide, was determined in small DODA bromide (DODAB) vesicles (1.5 mM DODAB) as solubilizers. It is $160,406 \mathrm{M}^{-1} \mathrm{~cm}^{-1}$. This shows that these cationic vesicles are excelent solubilizers for the drug since the molar absorptivity for the drug in its best solvent mixture (methanol/dimethylsulfoxide
1:1) is $164,300 \mathrm{M}^{-1} \mathrm{~cm}^{-1}$. Formulation of hydrophobic drugs will possibly be substantially improved by using DODAB vesicles as solubilizers. However, prospective DODAB uses cannot avoid a systematic evaluation of diferential toxicity for these cationic liposomes.

Table I illustrates the compared toxicity of DODAB liposomes for cultured mammalian cells and some bacteria or fungi. Mammalian cells are more resistant to DODAB than are bacteria or fungi remaining $50 \%$ viable at $1.0 \mathrm{~m} \mathrm{M}$ DODAB whereas, for the latter, $50 \%$ of viability occurs over the $m i$ cromolar range of DODAB concentrations. Mammalian cells remain ca. $100 \%$ alive at DODAB concentrations where bacteria and fungi do not survive. DODAB liposomes are prone to further uses as bactericides themselves in which multiple drugs against multiple infections can be included.

Determination of adsorption isotherms for lipids from liposomes onto latex, silica or bacteria followed by linearization of the langmuirian curves allows calculations of parameters as affinity constants and adsorption maxima (Jackson et al. 1986), which are valuable parameters to ascertain the product of the liposome/surface interaction (Table II). The occurrence of opposite charge for the liposome and surface pair generally drives deposition of one bilayer onto the latex or the silica particle. Examples for this are the interactions between large or small DODAB vesicles and latex where the cationic DODAB deposits as bilayers onto the negatively charged sulfate polystyrene particles. Similarly, interactions between small or large DHP vesicles and oppositely charged amidine polystyrene particles leads to deposition of DHP bilayers onto the latex (Table II). However, the negatively charged E. coli cell does not interact with cationic DODAB or DODAC vesicles leading to bilayer deposition. There is mere adhesion of entire vesicles at the cell surface. Given the roughness and complexity of the supramolecular assembly characteristic of the bacteria cell wall, which includes protuding sugars from glicolipids and lipoproteins, complex protein structures with multiple functions as recognition, 
TABLE I

Diferential cytotoxicity of cationic DODAB liposomes. Interaction time between small DODAB vesicles and cells was fixed at 1 h. Adapted from Carmona-Ribeiro et al. 1997, Campanhã et al. 1999.

\begin{tabular}{lcc}
\hline Cell type & $\begin{array}{c}\text { Viable cells concentration } \\
(\text { cells } / \mathrm{mL})\end{array}$ & $\begin{array}{c}\text { DODAB concentration for } \\
50 \% \text { survival }(\mathrm{mM})\end{array}$ \\
\hline Normal Balb-c 3T3 (clone A31) mouse fibroblasts & $10^{4}$ & 1.000 \\
SV40-transformed SVT2 mouse fibroblasts & $10^{4}$ & 1.000 \\
C. albicans & $2 \times 10^{6}$ & 0.010 \\
E. coli & $2 \times 10^{7}$ & 0.028 \\
S. typhimurium & $2 \times 10^{7}$ & 0.010 \\
P. aeruginosa & $3 \times 10^{7}$ & 0.005 \\
S. aureus & $3 \times 10^{7}$ & 0.006 \\
\hline
\end{tabular}

adhesion, transport, etc, it is not straightforward to achieve a simple explanation for the absence of cationic vesicle disruption at the cell surface. Neutral phospholipids such as PC or DPPC from vesicles deposits as an odd number of monolayers onto the amidine latex surface. This agrees with the interpretation of a first monolayer coverage on the solid surface with the phospholipid polar heads uppermost. In this case, adsorption would be basically driven by the hydrophobic attraction between the lipid hydrocarbon tails and the hydrophobic surface.

Table III shows how the cationic DODAB liposomes are useful to carry oppositelly charged biomolecules such as proteins or a nucleotide, 2'deoxyadenosine 5'-monophosphate. The cationic liposomes are useful as immunoadjuvants for induction of delayed type hypersensitivity towards the antigenic $18 \mathrm{kDa}$ heat-shock protein of M. leprae. Incorporation of the protein in the adjuvant liposomes increases the cellular immunoresponse ca. 10 times (Tsuruta et al. 1997). Besides the electrostatic attraction driving incorporation of the protein onto the liposome, there is also the hydrophobic attraction between the liposome and the protein that accounts for the large incorporation measured at higher salt concentrations (Table III). Bovine serum albumin (BSA) and anti-BSA incorporation onto the cationic liposomes is more sensitive to ionic strength than is incorporation of $\mathrm{hsp}-18 \mathrm{kDa}$ from M. Lep- rae (Table III). Incorporation substantially decreases when performed in PBS instead of water (Table III) showing the relative importance of electrostatics vs. hydrophobic forces determining protein incorporation in the liposome. The nucleotide in Table III is a typical case of partitioning molecule whose incorporation in the cationic bilayer requires the large electrostatic attraction that occurs in pure water at zero ionic strength.

\section{ACKNOWLEDGMENTS}

I thank FAPESP and CNPq grants and Ms. Renata Rapuano help in drawing Figure 1.

\section{REFERENCES}

Behr JP 1993. Synthetic gene-transfer vectors. Acc Chem Res 26: 274-278.

Campanhã MTN, Mamizuka EM \& Carmona-Ribeiro AM 1999. Interactions between cationic liposomes and bacteria: the physical-chemistry of the bactericidal action. J Lipid Res 40: 1495-1500.

Carmona-Ribeiro AM 1992. Synthetic amphiphile vesicles. Chem Soc Rev 21: 209-214.

Carmona-Ribeiro AM \& Herrington TM 1993. Phospholipid adsorption onto polystyrene microspheres. J Colloid Interface Sci 156: 19-23.

Carmona-Ribeiro AM \& Midmore BR 1992. Synthetic bilayer adsorption onto polystyrene microspheres. 


\section{TABLE II}

Affinities (K) and maximal adsorption ( $\mathrm{x}_{\max }$ ) for different liposome-forming amphiphiles onto a variety of organic, inorganic or biological surfaces. Models for organic synthetic surfaces are different types of latex (polystyrene) particles; for inorganic surfaces, conventional hydrophilic silica (Aerosil OX-50) and, for biological surfaces, E. coli cell surfaces. Liposomes were obtained from the following lipids: phosphatidylcholine (PC), dipalmytoilphosphatidylcholine (DPPC), dioctadecyldimethylammonium bromide (DODAB) or chloride (DODAC), sodium dihexadecylphosphate (DHP) or monosialoganglioside (GM1). Latex particles are quoted as sulfate polystyrene (SP) or amidine polystyrene (AP) followed by the mean latex diameter in $\mathrm{nm}$. Silica particles are Aerosil OX-50 (50 nm mean diameter) from Degussa. Adapted from Tápias et al. 1994, Campanhã et al. 1999, Carmona-Ribeiro \& Midmore 1992, Carmona-Ribeiro \& Herrington 1993, Sicchierolli \& Carmona-Ribeiro 1995, Sicchierolli et al. 1995, Rapuano \& Carmona-Ribeiro 1997.

\begin{tabular}{|c|c|c|c|c|}
\hline Liposome & Particle & $\begin{array}{c}\text { Affinity } \\
\text { constant, } \mathrm{K}\left(\mathrm{M}^{-1}\right)\end{array}$ & $\begin{array}{c}\text { Adsorption } \\
\text { maxima, } \mathrm{x}_{\max } \\
\left(\text { molecules per } m^{2}\right)\end{array}$ & $\begin{array}{l}\text { Lipid assembly } \\
\text { at the surface }\end{array}$ \\
\hline DODAB/SV & E. coli cell & 0.14 & $200 \times 10^{17}$ & $\begin{array}{l}\text { Entire small vesicles } \\
\text { adhered to the cell wall }\end{array}$ \\
\hline DODAC/LV & E. coli cell & 45.20 & $345 \times 10^{17}$ & $\begin{array}{l}\text { Large vesicles adhered to } \\
\text { the cell wall }\end{array}$ \\
\hline DODAB/SV & SP100 & $35.60 \times 10^{4}$ & $36 \times 10^{17}$ & Bilayer \\
\hline DODAB/LV & SP277 & $2.56 \times 10^{4}$ & $43 \times 10^{17}$ & Bilayer \\
\hline DODAC/LV & SP285 & $29.00 \times 10^{4}$ & $35 \times 10^{17}$ & Bilayer \\
\hline DHP/LV & AP850 & $75.00 \times 10^{4}$ & $53 \times 10^{17}$ & Multibilayers \\
\hline DHP/SV & AP97 & $51.00 \times 10^{4}$ & $55 \times 10^{17}$ & Bilayer \\
\hline $\mathrm{PC} / \mathrm{SV}$ & AP104 & $\begin{array}{c}50.00 \\
110.00\end{array}$ & $\begin{array}{l}14.5 \times 10^{17} \\
47.0 \times 10^{17}\end{array}$ & $\begin{array}{l}\text { Monolayer } \\
\text { Monolayer+Bilayer }\end{array}$ \\
\hline DPPC/SV & AP104 & $\begin{array}{c}56.00 \\
-\end{array}$ & $\begin{array}{l}20.0 \times 10^{17} \\
63.6 \times 10^{17}\end{array}$ & $\begin{array}{l}\text { Monolayer } \\
\text { Monolayer+Bilayer }\end{array}$ \\
\hline DODAB/SV & Silica50 & $63.70 \times 10^{4}$ & $34-70 \times 10^{17}$ & Bilayer+adhered vesicles \\
\hline GM1 micelles & $\begin{array}{l}\text { PC Mono+Bilayer } \\
\text { Covered AP172 }\end{array}$ & - & $1.7 \times 10^{17}$ & $\begin{array}{l}1 \mathrm{GM} 1 \text { per } 8 \mathrm{PC} \\
\text { molecules forming a layer } \\
\text { of adjacent sugar polar heads } \\
\text { at the bilayer/water interface }\end{array}$ \\
\hline
\end{tabular}

Langmuir 8: 801-806.

Carmona-Ribeiro AM, Ortis F, Schumacher RI \& ARMELIN MCS 1997. Interactions between cationic vesicles and cultured mammalian cells. Langmuir 13: $2215-2218$.

Carvalho LA \& Carmona-Ribeiro AM 1998. Interactions between cationic vesicles and serum proteins. Langmuir 14: 6077-6081.

FendLeR JH 1980. Surfactant vesicles as membrane mimetic agents: characterization and utilization. Acc Chem Res 13: 7-13.
JaCKSON S, Reboiras MD, LyLe IG \& Jones MN 1986. Adsorption of phospholipid vesicles on solid surfaces. Faraday Discuss Chem Soc 85: 291-301.

Kikuchi IS, Viviani W \& Carmona-Ribeiro AM 1999. Nucleotide insertion in cationic bilayers. J Phys Chem A 103: 8050-8055.

Lessa MM \& Carmona-Ribeiro AM 1996. Bilayer wetting on polymer surfaces. J. Colloid Interface Sci 182: $166-172$.

Martins LMS, Mamizuka EM \& Carmona-Ribeiro AM 1997. Cationic vesicles as bactericides. Lang- 


\section{TABLE III}

Incorporation (\%) of a variety of biomolecules onto cationic DODAB liposomes. Adapted from Tsuruta et al. 1997, Carvalho \& Carmona-Ribeiro 1998, Kikuchi et al. 1999.

\begin{tabular}{cccc}
\hline Liposome type and concentration & Biomolecule & Medium & Incorporation (\%) \\
\hline DODAB LV/ 2.6 mM & hsp 18 kDa (M. leprae $)$ & water & $94-100$ \\
& & PBS & $67-74$ \\
DODAB LV/ 4.0 mM & BSA & water & 100 \\
& & PBS & $32-35$ \\
& anti-BSA & water & $96-98$ \\
& & PBS & $26-31$ \\
DODAB LV/ 0.5 mM & 2'-deoxyadenosine & & \\
& 5'-monophosphate & water & $22-25$ \\
DODAB LV/ 0.5 mM & & 5mM NaBr & $2-4$ \\
\hline
\end{tabular}

muir 13: 5583-5587.

Rapuano R \& Carmona-Ribeiro AM 1997. Physical adsorption of bilayer membranes on silica. J Colloid Interface Sci 193: 104-109.

Sicchierolli SM \& Carmona-Ribeiro AM 1995. Incorporation of cholera toxin receptor in phospholipid-covered polystyrene microspheres. Colloid \& Surf B 5: 57-62.

Sicchierolli SM, Mamizuka EM \& Carmona-Ribeiro AM 1995. Bacteria flocculation and death by cationic vesicles. Langmuir 11: 2991-2995.
Tapias GN, Sicchierolli SM, Mamizuka EM \& Carmona-Ribeiro AM 1994. Interactions between cationic vesicles and Escherichia-coli. Langmuir 10: 3461-3465.

Tsuruta LR, Quintilio W, Costa MHB \& CARmonaRiBEIRo AM 1997. Interactions between cationic liposomes and an antigenic protein: the physical chemistry of the immunoadjuvant action. J Lipid Res 38: 2003-2011. 